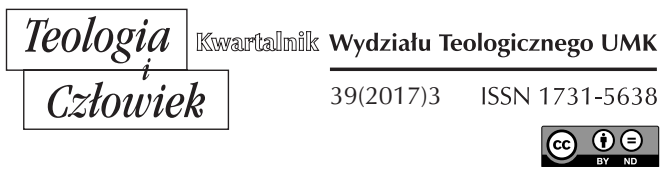

KS. PIOTR WIŚNIEWSKI*

LUBLIN

\title{
PRAKTYKA ALTERNATIM W RĘKOPIŚMIENNYM CANTIONALE (R. 583) Z JASNEJ GÓRY \\ DOI: http://dx.doi.org/10.12775/TiCz.2017.033
}

Okres wieków średnich w dziejach muzyki należy do niezwykle ciekawych i bardzo różnorodnych pod względem sukcesywnie tworzonego repertuaru. Każdy, kto interesuje się twórczością liturgiczną tego czasu, bez trudu stwierdzi, iż w ciągu tej ponad tysiącletniej epoki nastąpił niesłychany, fenomenalny rozkwit sztuki muzycznej. Począwszy od melodii jednogłosowych, poprzez proste dwugłosy, aż po skomplikowaną, kunsztowną polifonię późnego średniowiecza dokonywało się poszukiwanie coraz bardziej nowych form jej kreowania i wykonywania. Nastąpił wówczas, głównie w ośrodkach klasztornych, ogromny rozwój muzyki religijnej, którą Kościół wprowadzał do swojej liturgii, mszalnej

* Ks. Piotr Wiśniewski, dr hab. nauk humanistycznych w zakresie historii-muzykologii, kierownik Katedry Polifonii Religijnej Instytutu Muzykologii KUL. Należy do Towarzystwa Naukowego KUL, Stowarzyszenia Polskich Muzyków Kościelnych, Towarzystwa Naukowego Franciszka Salezego, Associazione Internazionale Studi di Canto Gregoriano (Deutschsprachige Sektion) oraz Związku Kompozytorów Polskich (Sekcja Muzykologów) (wisniewskipiotr@op.pl).

1 Z. Dobrzańska-Fabiańska, Polifonia średniowiecza, Kraków 2009. 
i brewiarzowej. Choć największą wartość przypisywano wyrafinowanej jednogłosowej muzyce wokalnej, przez długi okres jedynej uprawomocnionej w liturgii, to jednak $\mathrm{z}$ biegiem czasu następowało, chociaż bardzo powoli i z wielkimi oporami, wprowadzanie do obrzędów Kościoła Zachodniego także organów jako instrumentu muzycznego. Niechęć do nich była powodowana przede wszystkim kojarzeniem tego instrumentu przez Ojców Kościoła jako świecki, związany z obrzędami pogańskimi². Z chwilą jednak, gdy to niebezpieczeństwo minęło, władze kościelne stopniowo pozwalały nie tylko na towarzyszenie organom do śpiewów liturgicznych, ale także dopuszczały je jako instrument solowy, co zdecydowanie podniosło ich rangę. Oficjalne umieszczenie organów w kościołach datuje się na wiek VII (pontyfikat papieża Witaliana, 657-672), choć na trwałe nastąpiło to dopiero $\mathrm{w} X$ stuleciu $^{3}$. Wprowadzenie ich do liturgii związane było, rzecz jasna, z chorałem gregoriańskim. Najstarsza praktyka zastosowania tego instrumentu w liturgii polegała na przeplataniu śpiewów chóralnych wstawkami organowymi. Organy powtarzały unisono melodię psalmu, hymnu lub sekwencji. Tego typu alternowany sposób, nazwany alternatim, znany był w zachodniej Europie już w XIII wieku ${ }^{4}$ i polegał na dialogowaniu pomiędzy zespołem śpiewaczym a organami. Zdaniem Jerzego Morawskiego technika ta znana była już dużo wcześniej cystersom, którzy nie usunęli tego rodzaju wykonawstwa $\mathrm{z}$ benedyktyńskich przepisów liturgicznych ${ }^{5}$. Rozpowszechniła się ona do tego stopnia, że stała się powszechną praktyką zakonną podczas wspólnych modlitw brewiarzowych, a także w niektórych śpiewach mszalnych. Wymagała jednak od organisty biegłości w zakresie improwizacji związanej tematycznie $\mathrm{z}$ konkretnym śpiewem. Ślady tego typu praktyki spotykamy w interesującym nas rękopiśmiennym Cantionale R. 583 (olim I-215) z początku XVI wieku, należącym do tradycji paulińskiej. ${ }^{6}$. Celem podjętego studium jest

2 I. Pawlak, Organy - instrument liturgiczny, „Liturgia Sacra” 2 (1996) 1-2, s. 80; tenże, Muzyka instrumentalna w liturgii po Soborze Watykańskim II, „Liturgia Sacra” 18 (2012) 2, s. 514-15.

3 Tamże.

${ }^{4}$ H. Feicht, Studia nad muzyka polskiego średniowiecza, Kraków 1975, s. 314-315.

${ }^{5}$ J. Morawski, Polska liryka muzyczna $w$ średniowieczu. Repertuar sekwencyjny cystersów (XIII-XVI w.), Warszawa 1973, s. 250.

${ }^{6}$ Fakt ten zasygnalizował jako pierwszy J. Kubieniec, zob. Średniowieczne ręko- 
wydobycie na światło dzienne śpiewów zdradzających stosowanie techniki alternatim, a tym samym ujawnienie, iż w klasztorach paulińskich w XV wieku była ona okazjonalnie stosowana.

\section{TECHNIKA ALTERNATIM}

Alternowany sposób wykonania wokalno-instrumentalnego przejęty został z czysto wokalnej praktyki alternatim („na przemian”, łac. alter ad alterum $)^{7}$. Powstała ona w Kościołach wschodnich, gdzie odnosiła się do wykonywania przez dwa chóry, lub jeden chór podzielony na dwie części, naprzemiennie wersetów psalmów, hymnów, sekwencji oraz śpiewów responsorialnych. Ten sposób śpiewania przejął Kościół katolicki dla wykonywania chorału gregoriańskiego ${ }^{8}$. Znany był również bardziej okazały śpiew przez dwa naprzemienne chóry z towarzyszeniem instrumentów ${ }^{9}$. W późnym średniowieczu słowo alternatim oznaczało śpiewanie na przemian dwóch lub więcej równorzędnych chórów podczas liturgii, albo wymianę części jednogłosowych $\mathrm{z}$ wielogłosowymi ${ }^{10}$. Technika ta, zanim otrzymała ostateczny kształt, przeszła ewolucję różnych jej postaci:

pisy liturgiczne $z$ archiwum jasnogórskiego, w: Liturgia $w$ klasztorach paulińskich $w$ Polsce. Źródła i początki, red. R. Pośpiech, Musica Claromontana - Studia 1, Opole 2012, s. 138; Kubieniec czas powstania tego rękopisu określa na podstawie znaków wodnych. Na większości kart widnieje filigram z 1526 r., natomiast inne znaki wodne na pojedynczych kartach pochodzą z lat ok. 1506-1514. Według informacji na s. 141 kodeks ten znajdował się na Jasnej Górze co najmniej od 1601 r., tamże.

7 J. Morawski, Polska liryka muzyczna, s. 250.

8 A. Szadejko, Praktyka alternatim $w$ muzyce organowej. Zagadnienia wykonawcze, w: Musica Sacra 3, Prace Specjalne 73, red. J. Krassowski i in, Gdańsk 2007, s. 36.

${ }^{9}$ Najwcześniejsze świadectwa naprzemiennego wykonywania psalmów znajdujemy w pismach patrystycznych IV wieku. Według E. Wellesza tego typu praktyka istniała znacznie wcześniej. Wellesz przywołuje Filona (ur. ok. 30 r. przed Chrystusem), zdaniem którego podobny zwyczaj nie dotyczył wyłącznie kultu religijnego, E. Wellesz, Historia muzyki i hymnografii bizantyjskiej, Kraków 2006, s. 49-50.

10 Przykładem są m.in. Organa Leoninusa (ok. 1163-1190) i Perotinusa (ok. 1180-1230); wielkanocny graduał Haec dies; Missa Trompetta Estienna Grossina (ok. 1400); Credo z Kodeksu Trydenckiego nr 87 i in. Szczegółowo omawia je w swojej monografii S. Ferfoglia, Msza alternatim we włoskiej i francuskiej muzyce liturgicznej XVII wieku, Kraków 2011, s. 19-26. 
chorał gregoriański - śpiew wielogłosowy, polifonia „solistyczna” - polifonia „chóralna”, trzech solistów (w tym instrument trompetta) - większa grupa śpiewaków, weneckie techniki: cori spezzati, czyli naprzemienność: chór - chór oraz concertato: chór - instrumenty ${ }^{11}$. Wprowadzając w ten sposób więcej dynamiczności do tradycyjnego śpiewu jednogłosowego przygotowała grunt do zastąpienia z czasem drugiego chóru przez organy. Szczegółowo tym zagadnieniem zajęła się w swojej monografii S. Ferfoglia, dlatego też przywołamy $\mathrm{w}$ tym miejscu najważniejsze jej stwierdzenia. Trudno definitywnie wskazać, kiedy alternatim z muzyki wokalnej zaczęła przenikać do muzyki instrumentalnej. Wydaje się, iż nastąpiło to w sposób naturalny, ponieważ od dawna próbowano grą na instrumentach naśladować głos ludzki, improwizując na podstawie danej melodii i ozdabiając ja swobodnym kontrapunktem ${ }^{12}$. Fakt ten potwierdzają liczne opisy źródłowe, z których wynika, iż technika ta była obecna $\mathrm{w}$ formie improwizowanych wersetów organowych, wykonywanych na przemian ze śpiewem. Nie zawsze jednak wynika $\mathrm{z}$ tych źródeł, czy chodziło o naprzemienność, czy o zwykły akompaniament organowy, bowiem pojęcia te funkcjonowały niekiedy jako synonimy ${ }^{13}$. Najwcześniejsze przykłady tej techniki odnotowuje się w sekwencjach i tropach, które służyły niejednokrotnie jako wprowadzenie do określonej akcji liturgicznej i przedłużały muzykę procesyjną. Używane do tych ceremonii organy miały za zadanie prawdopodobnie wzbogacać melodię podstawową i ją ozdabiać14. Ponieważ budowa formalna sekwencji nawiązuje do wzorców bizantyjskiej muzyki świeckiej, w której naprzemienne wykorzystywanie organów ze śpiewem było powszechne na dworze królewskim, Susi Ferfoglia przypuszcza, że ten sposób stosowania organów i śpiewu wprowadzony został na Zachodzie pod wpływem kultury wschodniej ${ }^{15}$. W świetle przytoczonych przez nią licznych źródeł dowiadujemy się, że organy grały na przemian $\mathrm{z}$ chorałem ${ }^{16}$. Nie było jednak ujednoliconej reguły, według której nale-

11 Tamże, s. 26.

12 Tamże, s. 10.

13 Tamże, s. 27; M. Aleksandrowicz, Teoretyczne podstawy francuskiej polifonii liturgicznej XVII wieku, Lublin 2017, s. 77.

14 S. Ferfoglia, Msza alternatim, s. 28.

15 Tamże.

16 Tamże, s. 28 nn. 
żało posługiwać się techniką alternatim. Cechowała się ona bowiem dość dużym stopniem skomplikowania. Jej stosowanie doprowadziło w konsekwencji do tego, że co drugi werset tekstu liturgicznego był opuszczany i zastępowany solową grą organową ${ }^{17}$. Przeciwny tej formie był jednak Sobór Trydencki (1545-1563), który domagał się wykonywania kompletnych tekstów liturgicznych, tzn. bez opuszczania ich części i zastępowania muzyką organową ${ }^{18}$. Głos $\mathrm{w}$ tej sprawie zabrały następnie różne lokalne synody (np. w Reims 1564, czy w Cambrai 1565) ${ }^{19}$, które w swych uchwałach jednoznacznie stwierdziły, iż powinno się wrócić do proklamowania pełnych tekstów, a zwłaszcza Credo, w którym wierni wyznają swoją wiarę. Dlatego zalecono jego śpiewanie w całości przez chór. Podobne ograniczenia wydawano także w stosunku do innych śpiewów, np. sekwencji, hymnów, Gloria, Sanctus, choć niekiedy pomiędzy samymi synodami można zaobserwować pewne rozbieżności w tej kwestii ${ }^{20}$. Kolejne regulacje w tej kwestii podejmowano pod koniec XVI i na początku wieku XVII. Idąca po linii wyznaczonej przez Tridentinum księga Caeremoniale Episcoporum z 1600 roku oficjalnie określa udział organów w śpiewach liturgicznych jako alternacji. W świetle zapisanych $\mathrm{w}$ dokumencie odnośnych norm w czasie Mszy uroczystej (Missa solemnis) organy grają alternatim na Kyrie eleison, Gloria, Sanctus i Agnus Dei, natomiast na Credo mają milczeć. Ta część powinna być wykonywana w całości w sposób monodyczny przez chór (scholę) $)^{21}$. W praktyce jednak zalecenia te nie były stosowane wszędzie jednakowo. Pewne ujednolicenie odnośnych reguł o zasięgu narodowym nastąpiło $\mathrm{w}$ XVII wieku ${ }^{22}$. Wszystkie przytoczone wyżej fakty świadczą jednoznacznie o tym, iż technika alternatim była powszechna w liturgii i cieszyła się dużym powodzeniem. Nie ulega wątpliwości, iż dzięki niej coraz większą rolę w Kościele zaznaczały organy. Gros literatury

17 Tamże, s. 54.

18 Tamże.

19 M. Aleksandrowicz, Teoretyczne podstawy, s. 85.

20 S. Ferfoglia, Msza alternatim, s. 55.

${ }^{21}$ M. Aleksandrowicz, Organy w potrydenckiej liturgii na podstawie Caeremoniale Episcoporum (1600), w: Studia Organologica, t. 3, red. M. Szymanowicz, Lublin 2009, s. 258; Caeremoniale Episcoporum określa również możliwości stosowania techniki alternatim podczas Officium divinum, tamże, s. 262-263.

22 A. Szadejko, Praktyka alternatim, s. 37. 
organowej, przynajmniej do końca XVII wieku, podporządkowane było funkcji towarzyszenia liturgii. Technika alternacyjna była najważniejszym i najstarszym sposobem użycia organów ${ }^{23}$. Muzyka organowa nie stanowiła jednak akompaniamentu dla chorału gregoriańskiego. Organy wykonywały konkretne wersety śpiewu zamiast chóru. Możemy zatem stwierdzić, iż to właśnie chorał gregoriański, który odgrywał w liturgii Kościoła katolickiego od samego początku znaczącą rolę, stał się także niekwestionowanym inspiratorem organowej muzyki liturgicznej, która czerpała swe natchnienie $\mathrm{z}$ tego śpiewu. U schyłku średniowiecza służyła ona bowiem do przeplatania wierszy psalmowych, kantyków i mszalnego Gloria $^{24}$ odgrywaniem ich melodii. W ten sposób zrodziła się praktyka alternatim, oparta na chorale i swobodnie improwizująca motywy gregoriańskie $^{25}$. Jej uprawianie w liturgii stawiało jednocześnie organistom konkretne wymagania $\mathrm{w}$ zakresie gry organowej, bowiem $\mathrm{w}$ miarę jej rozwoju wersety organowe zaczęły przybierać różne formy, niezależnie od wzorca gregoriańskiego, pozostając jednak w określonym modusie lub przygotowując właściwy ton dla następnego śpiewanego odcinka ${ }^{26}$.

\section{2.ŚPIEWY ALTERNATIM W KODEKSIE R. 583.}

Cantionale R. 583 notuje łącznie cztery śpiewy, w których zauważono praktykę alternatim. Są to trzy antyfony maryjne: Salve Regina, Ave Regina caelorum i Regina caeli oraz Credo. Nie jest to wprawdzie imponujący repertuar, niemniej jednak dowodzący, iż w zakonie paulinów praktykowano ten sposób wykonywania śpiewów liturgicznych. Według opinii J. Kubieńca rękopis pauliński nie został najpewniej spisany w Pol-

23 Tamże, s. 35.

${ }^{24}$ Najstarszy przekaz alternowanego Gloria z terenu Polski reprezentuje rękopis z Żagania. Zamieszczony w nim hymn daje podstawę do przeprowadzenia jego rekonstrukcji wykonawczej: Gloria in excelsis Deo - chór, Et in terra pax hominibus bone voluntatis - organy, Laudamus te - chór, Benedicimus te - organy, Adoramus te - chór, Glorificamus te - organy, zob. J. Morawski, Polska liryka muzyczna, s. 266.

25 P. Wiśniewski, Duchowość chorału gregoriańskiego, „Liturgia Sacra” 19 (2013) nr 1, s. 116.

${ }^{26}$ A. Szadejko, Praktyka alternatim, s. 36. 
sce, o czym świadczy m.in. brak w nim śpiewów o św. Wojciechu i św. Stanisławie oraz zastosowana ostrzyhomska notacja muzyczna i tekst w języku węgierskim (s. 386). Jednak według krótkiej noty na s. 141 (Iste liber spectat ad montem clarum Czestochoviensem Anno Domini 1601) na Jasnej Górze znajdował się on co najmniej od $1601 \mathrm{roku}^{27}$. Z kolei na podstawie dokumentacji organologicznej wiadomo, iż w bazylice jasnogórskiej oraz w kaplicy obrazu Matki Bożej organy zostały wybudowane w latach 1721-25 przez Adama Horatio Caspariniego (1674-1745) ${ }^{28}$. Fakt ten pozwala $\mathrm{w}$ związku $\mathrm{z}$ tym przypuszczać, iż wymienione wyżej śpiewy w technice alternatim mogły być wykonywane również na Jasnej Górze.

Organy zastępując chór śpiewaków musiały spełniać równoważną rolę, analogiczną do operowania tekstem liturgicznym. Znajomość tekstów sprawiała, że organy mogły swobodnie zastępować w danym miejscu tekst liturgiczny. Nie byłoby to jednak możliwe, gdyby wykonywane utwory nie były powszechnie znane. Dlatego też, jak zaznacza A. Szadejko, praktyka alternacyjna ograniczała się do tych tekstów chorału, które były szczególnie często śpiewane podczas liturgii ${ }^{29}$. Nie ulega wątpliwości, iż do takich należały $\mathrm{m}$.in. wielkie antyfony maryjne i wyznanie wiary.

\subsection{SALVE REGINA}

Jednym z pierwszych utworów, w którym zaznaczono propozycję alternacji, jest antyfona maryjna Salve Regina. Jest to najstarsza spośród czterech klasycznych antyfon maryjnych, obok Alma Redemptoris Mater, Ave Regina caelorum i Regina caeli ${ }^{30}$. Dotychczas pochodzenie tekstu i melodii Salve Regina nie zostało jednoznacznie określone. Jako miejsce powstania tej kompozycji wskazuje się katedrę w Le Puy, a jej tekst notują tamtejsze rękopisy z XI i XII stulecia, co sugeruje jednocześnie czas powstania utworu ${ }^{31}$. Jeszcze więcej kontrowersji wśród badaczy wzbudza

27 J. Kubieniec, Średniowieczne rękopisy liturgiczne, s. 138.

${ }_{28}$ W.Z. Łyjak, Adam Orazio Casparini i jego jasnogórskie dzieła, „Studia Claromontana" 20 (2002), s. 141-191.

${ }^{29}$ A. Szadejko, Praktyka alternatim, s. 36.

30 B. Nadolski, Leksykon Liturgii, Poznań 2006, s. 1442.

${ }^{31}$ S. Garnczarski, Atyfona Salve Regina w polskich przekładach zachowanych 
problem autorstwa tej antyfony. Wskazuje się przynajmniej na pięciu: Piotra, biskupa Compostelli (zm. 1020), Hermanusa Contractusa (zm. 1054), biskupa Adhemara z Monteuil (zm. 1098/99), biskupa o imieniu Podium (XII/XIII w.) oraz Bernarda z Clairvaux (zm. 1153). Początkowo śpiew ten związany był ze środowiskiem cystersów, gdzie wykonywano go przed Ewangelią w cztery święta maryjne: Oczyszczenia, Zwiastowania, Wniebowzięcia i Narodzenia ${ }^{32}$. Antyfona ta stopniowo jednak zyskiwała swoją popularność w całym Kościele Powszechnym, do czego w znaczącym stopniu przyczynili się franciszkanie, wykonując ją na zakończenie Completorium $^{33}$. Najczęściej była ona odśpiewywana w procesjach średniowiecznych i określana jako „chwalebna” (antiphona gloriosa) ${ }^{34}$. Utwór ten w warstwie tekstowej, jako jedyny spośród wymienionych antyfon maryjnych, nie jest dziełem poetyckim, tylko rymowaną prozą w specjalnej formie, jako tzw. "pozdrowienie upraszające” (salutatio deprecatoria) ${ }^{35}$. W takiej postaci notuje ją Cantionale R. 583. Jej wykonywanie na sposób alternatim zdradzają oznaczenia organum ${ }^{36} \mathrm{i}$ chorus, pisane naprzemiennie nad kolejnymi wersetami śpiewu, choć nie do końca kompozycji (tylko na k. 15r), w następującym porządku:

organum: Salve Regina (...) misericordiae,

chorus: vita dulcedo et spes nostra salve.

organum: Ad te clamamus exsules filii Hevae,

chorus: Ad te suspiramus gementes et flentes in hac lacrimarum valle. organum: Eia ergo advocata nostra illos tuos misericordes oculos ad nos converte.

$w$ źródłach drukowanych, w: Cantare amantis est. Wieloautorska monografia naukowa $z$ okazji 80. urodzin ks. prof. dr. hab. Ireneusza Pawlaka, red. W. Hudek, P. Wiśniewski, Lublin 2015, s. 309.

32 Tamże.

${ }_{33}$ B. Bodzioch, Cantionale ecclesasticum na ziemiach polskich $w$ XIX i XX wieku, Lublin 2014, s. 144.

34 T. Michałowska, Średniowiecze, Warszawa 2002, s. 378.

35 S. Garnczarski, Atyfona Salve Regina, s. 309.

${ }^{36}$ Gilles de Zamore w XIII wieku stwierdza, iż chociaż termin organo może odnosić się do każdego rodzaju instrumentu muzycznego, to jednak organy w znaczeniu instrumentu piszczałkowego są jedynym instrumentem dopuszczanym przez Kościół do towarzyszenia śpiewom, m.in. podczas wykonywania hymnów i sekwencji, M. Aleksandrowicz, Teoretyczne podstawy, s. 84. 
(chorus): Et Jesum benedictum fructum ventris tui nobis post hoc exsilium ostende.

(organum): O clemens,

(chorus): $O$ pia,

(organum): $O$ dulcis Virgo Maria.

W nawiasach zasugerowano brakujące oznaczenia alternacyjne na karcie $15 \mathrm{v}$, których $\mathrm{z}$ niewiadomych powodów nie zaznaczył skryptor w dalszej części antyfony. Ich pominięcie może świadczyć na przykład o dobrej znajomości zasad alternatim wśród wykonawców, a co za tym idzie, o jej wcześniejszym stosowaniu. Trudno bowiem przyjąć, iż tylko w części śpiewu stosowano tę technikę. Kłóciłoby się to w oczywisty sposób z regułami tej praktyki wykonawczej.

Antyfona Salve Regina jest ciekawym przykładem wczesnego wykorzystania techniki alternatim. Partie organowe dotyczą bowiem zawsze wersetów nieparzystych: Salve Regina; Ad te clamamus; Eia ergo; $O$ clemens; $O$ dulcis, natomiast wersety parzyste śpiewano jednogłosowo. Charakterystyczne dla tej formy było również opracowywanie wersetów parzystych w sposób wielogłosowy. W ten sposób ukształtowały się dwa typy praktyki wykonawczej ${ }^{37}$.

Manuskrypt jasnogórski bezpośrednio po Salve Regina notuje dwie pozostałe wyżej wymienione antyfony maryjne: Ave Regina caelorum i Regina caeli, jednak bez oznaczeń alternacyjnych. $Z$ wyraźnym zaznaczeniem alternatim podano je ponownie dopiero w końcowej partii manuskryptu (s. 387). Fakt ten świadczy o pewnej dowolności naprzemiennego wykonywania tych śpiewów $\mathrm{z}$ organami lub tez w zależności od charakteru obchodzonego święta.

\subsection{AVE REGINA CAELORUM}

Tekst tej antyfony znajduje się w XII-wiecznym antyfonarzu z St-Maur-des-Fossés. Według tradycji miał ją ułożyć św. Bernard z Clairvaux (zm. 1153), choć w swej formie zdradza pewne odniesienia do wschod-

37 A. Szadejko, Praktyka alternatim, s. 40. 
nich akatystów ${ }^{38}$. Powstała ona w XI-XII w., co sugerują występujące $\mathrm{w}$ tekście tytuły maryjne ${ }^{39}$. Antyfona ta przeznaczona była dawniej od święta Ofiarowania Pańskiego do Wielkiego Czwartku ${ }^{40}$. W liturgii posoborowej można ją stosować ad libitum, tzn. bez wiązania jej z konkretnym okresem liturgicznym ${ }^{41}$, choć zwyczajowo wykonuje się ją na zakończenie Completorium w okresie Wielkiego Postu ${ }^{42}$.

Gdy chodzi o zastosowanie techniki alternatim w tej antyfonie, kodeks pauliński zaznacza wyraźnie jedynie partie organowe, notując czerwonym inkaustem wyrażenie organo. W nawiasach podajemy brakujące oznaczenia, wynikające $\mathrm{z}$ wyraźnego podziału tekstu na odcinki za pomocą divisio maior:

(organo): Ave Regina caelorum, (chorus): Ave Domina Angelorum organo: Salve radix, salve porta, Ex qua mundo lux est orta. (chorus): Gaude Virgo gloriosa, Super omnes speciosa, organo: Vale o valde decora, Et pro nobis Christum exora.

Także w przypadku tej antyfony wersety nieparzyste powierzone są organom. Warto w tym miejscu przywołać Caeremoniale parisiense z 1662 roku. Wyraźnie zaznaczono w nim, iż wszystkie wielkie antyfony maryjne musiały być $\mathrm{z}$ łatwością rozpoznawalne przez wiernych, dlatego organiście nie wolno było w pierwszym i ostatnim wersecie wprowadzać zmian $\mathrm{w}$ melodii $\mathrm{w}$ postaci diminucji, alteracji, czy zapożyczeń $\mathrm{z}$ innych śpiewów ${ }^{43}$. Uwaga ta oznacza zatem, iż jedynie w środkowych partiach organowych wolno było organiście improwizować.

${ }^{38}$ E. Wellesz, Historia muzyki, s. 214-219.

${ }^{39}$ W. Pałęcki, Antyfony maryjne na zakończenie Komplety w polskiej edycji Liturgii godzin, w: Mirabile laudis canticum. Liturgia godzin: dzieje i teologia, red. H. Sobeczko, Opole 2008, s. 369.

${ }^{40} \mathrm{~K}$. Lisman, Repertuar gregoriański w polskich śpiewnikach katolickich wydanych po Vaticanum Secundum, w: Muzyka liturgiczna w Kościele Katowickim 1925-2005, red. W. Hudek, Katowice 2005, s. 166.

${ }^{41}$ P. Wiśniewski, Monodia łacińska w XLI edycji Śpiewnika kościelnego ks. Jana Siedleckiego, „Teologia i Człowiek” 30 (2015) nr 2, s. 119.

42 W. Pałęcki, Antyfony maryjne, s. 369.

${ }^{43}$ Cyt. za: S. Ferfoglia, Msza alternatim, s. 115. 


\subsection{REGINA CAELI}

Tekst tej antyfony przypisywany jest papieżowi Grzegorzowi V (996-999). Znajduje się w rękopisach z XII wieku. Notuje ją m.in. antyfonarz kościoła św. Piotra w Rzymie z 1171 roku, w którym występuje ona jako antyfona do Magnificat w oktawie Paschy. Wzorcem dla tej antyfony mogła być jedna ze zwrotek hymnu bożonarodzeniowego z XI wieku ${ }^{44}$. Szczególnie podatny grunt znalazła u franciszkanów. Za sprawą Kapituły Braci Mniejszych w Pizie postanowiono od 1263 roku śpiewać ją w okresie wielkanocnym, dodając po każdym wersecie alleluia. Około 1350 roku zwyczaj ten przyjęła również kaplica papieska. Śpiew ten nazwano antyfoną maryjną ok. 1743 roku i zarezerwowano jej wykonywanie w okresie wielkanocnym. Papież Benedykt XIV (1740-1758) zarządził jej odmawianie w miejsce Angelus Dimini ${ }^{45}$.

Cantionale R. 583 notuje ją z alleluia po każdym wersecie i z wyraźnie zaznaczonymi wersetami dla organów (organo) i chóru (chorus), odpowiadającym technice alternatim:
organo: Regina caeli laetare alleluia, chorus: Quia quem meruisti portare alleluia, organo: Resurrexit sicut dixit alleluia, chorus: Ora pro nobis Deum organo: alleluia.

Analogicznie, jak w przypadku dwóch poprzednich antyfon, wersety nieparzyste powierzone zostały organom. Wspólną cechą wszystkich trzech antyfon jest to, iż każdą z nich rozpoczynały organy. Było to zgodne z zasadą praktyki alternatim, zgodnie z którą organy nie grały pierwszego wersetu w psalmach, kantykach, hymnach, Tantum ergo, czy wersetach odnoszących się do Trójcy Świętej (Gloria Patri). Wynikało to głównie z powodów praktycznych, aby nie sprawiać trudności z intonacją antyfony i psalmu ${ }^{46}$. W świetle przedstawionych antyfon maryjnych wynika, iż

${ }^{44}$ W. Pałęcki, Antyfony maryjne, s. 370-371.

45 Tamże, s. 371.

${ }^{46}$ Szczegółowo reguluje to Caeremoniale Episcoporum w XXVIII rozdziale pierwszej księgi, zob. S. Ferfoglia, Msza alternatim, s. 65; por. A. Szadejko, Praktyka alternatim, s. 39. 
rękopis pauliński respektował szczegółowe normy dotyczące stosowania techniki alternatim.

\subsection{CREDO}

Zachód przejął Credo z liturgii wschodnich. Do liturgii mszalnej trafiło ono za pośrednictwem liturgii chrzcielnej, najpierw w Hiszpanii, a następnie w Irlandii i Anglii. W Kościele Zachodnim śpiew ten rozprzestrzeniał się jednak powoli. Do mszy rzymskiej wprowadził go papież Benedykt VIII (1012-1024) ${ }^{47}$. Początkowo wykonywano go wyłącznie w niedziele i uroczystości. Dopiero z biegiem czasu wprowadzono je do obchodów ku czci NMP, aniołów i świętych ${ }^{48}$. Gdy chodzi o jego wykonywanie, z zasady należało ono do całego zgromadzenia liturgicznego, o czym informują źródła z terenów Galii i Hiszpanii. Z czasem, z uwagi na trudności językowe, przejęło je duchowieństwo. Natomiast po reformie karolińskiej śpiewało je całe zgromadzenie. W praktyce jednak obowiązywała inna praktyka, mianowicie ludy germańskie nie odmawiały wyznania wiary w całości z uwagi na dość długi i trudny tekst ${ }^{49}$. Praktyka wykonawcza Credo przechodziła zatem różne przeobrażenia, początkowo śpiew ten podejmował lud, później zastępował go kler, schola lub chór. Pomimo zakazów Symbol śpiewano często, co szczególnie nas interesuje, także na przemian $\mathrm{z}$ organami ${ }^{50}$. Wzmianki o tej praktyce sięgają XIV wieku ${ }^{51}$. W opracowaniach Credo stosowano często identyczny schemat, jak w Gloria (Credo in unum Deum - chorał gregoriański, Patrem omnipotentem... - organy itd.). Jego wykonywanie nie było uregulowane przez dokumenty kościelne aż do Soboru Trydenckiego, który to nakazał tekst Credo w całości recytować lub śpiewać w celu dobrego rozumienia przez

47 I. Pawlak, Muzyka liturgiczna po Soborze Watykańskim II w świetle dokumentów Kościoła, Lublin 2000, s. 308-309.

${ }^{48}$ B. Bartkowski, Credo, Encyklopedia Katolicka, t. 3, red. R. Łukaszyk, Lublin 1985, kol. 626.

49 I. Pawlak, Muzyka liturgiczna, s. 309.

${ }^{50}$ Praktyka ta wyglądała różnie, np. u dominikanów była ona stanowczo zabroniona.

${ }^{51}$ I. Pawlak, Muzyka liturgiczna, s. 309. 
wiernych jego treści ${ }^{52}$. Orzeczenie to powtarza również Caeremoniale Episcoporum z 1600 roku: „Sed cum dicitur Symbolum in Missa, non est intermiscendum, sed ea per chorum cantu intellgibili proferatur" ${ }^{23}$.

W praktyce w alternacyjnym Credo funkcjonowały specyficzne rozwiązania regionalne, charakterystyczne dla wczesnego okresu w literaturze organowej. Na podstawie badań przeprowadzonych przez S. Ferfoglię dowiadujemy się, iż na przykład XVI-wieczne włoskie opracowania Credo melodię chorałową $\mathrm{w}$ wersetach organowych traktują $\mathrm{w}$ różny sposób. Bywa, że partie organowe są rozszerzone i zawierają całą melodię danego wersetu chorałowego lub też są bardzo zwięzłe i posiadają tylko początek wersetu chorału. $Z$ kolei mniejszy udział organów odnotowują źródła spoza Włoch. Badaczka wskazuje na Credo z druku P. Attaingnanta, gdzie organy grają początkowy werset: Patrem omnipotentem oraz Visibilium omnium et invisibilium, tzn. początek i koniec drugiego wersetu, natomiast część środkowa: factorem caeli et terrae, jest śpiewana. Organy zastępują następnie wersety: 4 (Et ex Patre), 8 (Et incarnatus est), 17 (Et exspecto) i 19 (Amen). Jeszcze bardziej ograniczony udział organów podaje Tabulatura Jana $z$ Lublina (1537). W czterech opracowaniach alternacyjnych Credo każde z nich obejmuje tylko dwa wersety organowe: Patrem omnipotentem (nr 2) i Qui propter nos homines ( $\mathrm{nr} 7)^{54}$. W świetle przedstawionych przykładów widać, iż alternacja tego śpiewu była dość zróżnicowana.

W interesującym nas Cantionale jasnogórskim wygląda ona następująco:

organum:

Patrem omnipotentem, factórem caeli et terrae, visibilium ómnium et invisibilium. Et in, unum Dóminum Iesum Christum, Filium Dei unigenitum, et ex Patre natum ante ómnia saecula. chorus:

Deum de Deo, lumen de lumine, Deum verum de Deo vero, genitum non factum, consubstantialem Patri, per quem ómnia facta sunt.

${ }^{52}$ S. Ferfoglia, Msza alternatim, s. 51.

53 „Podczas Wyznania wiary organy nie powinny jednak się włączać, ale cały ten tekst powinien być wyraziście odśpiewany przez chór”, cyt. za: S. Ferfoglia, Msza alternatim, s. 66.

${ }^{54}$ Tamże, s. 52. 
organum:

Qui propter nos hómines et propter nostram salutem descendit de caelis. chorus:

Et incarnatus est de Spiritu Sancto ex Maria Virgine, et homo factus est. Crucifixus etiam pro nobis sub Póntio Pilato; passus et sepultus est, et resurrexit tertia die, secundum Scripturas, et ascendit in crelum, sedet ad dexteram Patris. Et iterum venturus est cum glória, iudicare vivos et mórtuos, cuius regni non erit finis.

chorus:

Et in Spiritum Sanctum, Dóminum et vivificantem: qui ex Patre Filióque procedit. Qui cum Patre et Filio simul adoratur et conglorificatur, qui locutus est per prophetas. Et unam, sanctam, cathólicam et apostólicam Ecclesiam. Confiteor unum baptisma in remissiónem peccatorum. Et expecto resurrectiónem mortuórum, et vitam venturi saeculi. Amen.

Trudno wskazać zatem jednoznaczną obowiązującą regułę alternacji Credo. Być może było to spowodowane stopniowymi zakazami stosowania tej praktyki w przypadku wyznania wiary, pod wpływem których wykształciły się dość zróżnicowane, lokalne rozwiązania. Cechą wspólną dla tego śpiewu, i chyba jedyną, było to, iż jego rozpoczęcie należało do celebransa, a organy włączały się dopiero od drugiego wersetu. Generalna zasada alternatim polegała na tym, że we wczesnych źródłach przeważają formy, w których organy i chór wykonują na przemian grupy wersetów, natomiast od połowy XVII wieku następuje bardziej regularny podział na pojedyncze lub podwójne wersety ${ }^{55}$. W przypadku prezentowanego Credo mamy do czynienia $\mathrm{z}$ wyraźnym podziałem wersetów na grupy. $\mathrm{O}$ ile w przypadku przedstawionych wyżej antyfon maryjnych można mówić o pewnych zasadach ich alternacji, o tyle w odniesieniu do Credo ujawnia się niewątpliwie tradycja lokalna, ciążąca ku zachowaniu swej autonomiczności.

Wydobyte z jasnogórskiego Cantionale śpiewy z możliwością zastosowania praktyki alternatim przedstawiają zatem związek tej techniki z muzyką wokalną, którą w pewnym momencie zaczęto naśladować przez organy, co w późnym średniowieczu było dość popularne. W ten sposób zamiast relacji śpiew solowy - chór powstała alternacja organy - śpiew monodyczny. Przywołane przykłady kompozycji dowodzą, iż ten efek-

55 A. Szadejko, Praktyka alternatim, s. 44. 
towny sposób naprzemiennego, wokalno-instrumentalnego wykonywania śpiewów mszalnych i brewiarzowych znalazł swoje miejsce również w obrębie łacińskiej liturgii paulińskiej, gdzie stanowił zdecydowanie najbardziej odświętną formę muzycznego ornamentowania uroczystości maryjnych i wymagał zarazem odpowiednich kompetencji muzycznych od wykonawców. Odegrał on jednocześnie duże znaczenie w koncepcji formy, zapewniając przejrzyste rozczłonkowanie odcinkowe, pozwalające na respektowanie budowy wersowej tekstów. Zachowane jasnogórskie źródło pozwala sądzić, iż tego typu urozmaicenie fakturalne, zapoczątkowujące rozwój liturgicznego kunsztu kompozytorskiego, było zapewne także wyrazem chęci sukcesywnego podnoszenia muzyki kościelnej w klasztorach paulińskich na coraz wyższy poziom artystyczny.

Streszczenie. W rozwoju praktyki wykonawczej monodii liturgicznej dużą rolę odegrała technika alternatim, z którą związana jest znaczna część muzyki organowej. Organy zastępując chór śpiewaków spełniały równoważną rolę, analogiczną do operowania tekstem liturgicznym. Wykonywane na sposób alternatim utwory musiały być powszechnie znane. Do takich należały m.in. wielkie antyfony maryjne i wyznanie wiary. Ten wokalno-instrumentalny sposób wykonywania śpiewów łacińskich spotykamy również w rękopiśmiennym Cantionale R. 583 z początku XVI wieku, należącym do tradycji paulińskiej. Notuje on łącznie cztery śpiewy, w których zauważono praktykę alternatim: Salve Regina, Ave Regina caelorum, Regina caeli i Credo. W świetle przedstawionych antyfon maryjnych i założeń techniki alternatim wynika, iż rękopis pauliński respektował szczegółowe normy dotyczące jej stosowania, natomiast w przypadku Credo mamy do czynienia raczej z pewną tradycją lokalną. Przywołane przykłady dowodzą, iż sposób wokalno-instrumentalnego wykonywania śpiewów znalazł swoje miejsce również w obrębie łacińskiej liturgii paulińskiej.

Słowa kluczowe: alternatim; cantionale; chorał gregoriański; antyfony maryjne; Credo.

Abstract. Alternatim Practice in the Manuscript Cantionale (R. 583) From Jasna Góra. An important role in developing the performance practice of liturgical monody was played by the alternatim technique, which a lot of organ music is related to. The organ, replacing the choir of singers, performed a function which was analogical to the one of managing a liturgical text. Compositions performed in the alternatim way must have been widely known. They comprised, among others, great Marian antiphons and the Credo. This vocal - instrumental mode of performing Latin chant can also be found in the manuscript Cantionale R. 583 from the beginning of the 16th century, belonging to the Pauline tradition. There are four chants altogether in which the practice 
of alternatim is visible: Salve Regina, Ave Regina caelorum, Regina caeli and Credo. In the light of the presented Marian antiphons and the foundations of the alternatim technique, it can be inferred that the Pauline manuscript conformed to the precise rules of using this technique whereas in Credo it is rather a local tradition. The given examples prove that the vocal and instrumental manner of performing chants was also present in the Latin Pauline liturgy.

Key words: alternatim; cantionale; Gregorian chant; Marian antiphons; Credo.

\section{BIBLIOGRAFIA:}

Aleksandrowicz M., Organy w potrydenckiej liturgii na podstawie Caeremoniale Episcoporum (1600), w: Studia Organologica, t. 3, red. M. Szymanowicz, Lublin 2009, s. $257-265$.

Aleksandrowicz M., Teoretyczne podstawy francuskiej polifonii liturgicznej XVII wieku, Lublin 2017.

Bartkowski B., Credo, Encyklopedia Katolicka, t. 3, red. R. Łukaszyk, Lublin 1985, kol. 626.

Bodzioch B., Cantionale ecclesiasticum na ziemiach polskich w XIX i XX wieku, Lublin 2014.

Dobrzańska-Fabiańska Z., Polifonia średniowiecza, Kraków 2009.

Feicht H., Studia nad muzyka polskiego średniowiecza, Kraków 1975.

Ferfoglia S., Msza alternatim we włoskiej i francuskiej muzyce liturgicznej XVII wieku, Kraków 2011.

Garnczarski S., Atyfona Salve Regina w polskich przekładach zachowanych w źródłach drukowanych, w: Cantare amantis est. Wieloautorska monografia naukowa z okazji 80. urodzin ks. prof. dr. hab. Ireneusza Pawlaka, red. W. Hudek, P. Wiśniewski, Lublin 2015, s. 306-327.

Kubieniec J., Średniowieczne rękopisy liturgiczne $z$ archiwum jasnogórskiego, w: Liturgia w klasztorach paulińskich w Polsce. Źródła i początki, Musica Claromontana Studia 1, red. R. Pośpiech, Opole 2012, s. 135-149.

Lisman K., Repertuar gregoriański w polskich śpiewnikach katolickich wydanych po Vaticanum Secundum, w: Muzyka liturgiczna w Kościele Katowickim 1925-2005, red. W. Hudek, Katowice 2005, s. 155-180.

Łyjak W.Z., Adam Orazio Casparini i jego jasnogórskie dzieła, „Studia Claromontana” 20 (2002), s. 141-191.

Michałowska T., Średniowiecze, Warszawa 2002.

Morawski J., Polska liryka muzyczna w średniowieczu. Repertuar sekwencyjny cystersów (XIII-XVI w.),Warszawa 1973.

Nadolski B., Leksykon Liturgii, Poznań 2006.

Pałęcki W., Antyfony maryjne na zakończenie Komplety w polskiej edycji Liturgii godzin, 
w: Mirabile laudis canticum. Liturgia godzin: dzieje i teologia, red. H. Sobeczko, Opole 2008, s. 363-382.

Pawlak I. Muzyka instrumentalna w liturgii po Soborze Watykańskim II, „Liturgia Sacra” 18 (2012) nr 2, s. 513-527.

Pawlak I., Muzyka liturgiczna po Soborze Watykańskim II w świetle dokumentów Kościoła, Lublin 2000.

Pawlak I., Organy - instrument liturgiczny, „Liturgia Sacra” 2 (1996) nr 1-2, s. 79-85.

Szadejko A., Praktyka alternatim w muzyce organowej. Zagadnienia wykonawcze, w: Musica Sacra 3, Prace Specjalne 73, red. J. Krassowski, Gdańsk 2007, s. 35-55.

Wellesz E., Historia muzyki i hymnografii bizantyjskiej, Kraków 2006.

Wiśniewski P., Duchowość chorału gregoriańskiego, „Liturgia Sacra” 19 (2013) nr 1, s. 103-118.

Wiśniewski P., Monodia łacińska w XLI edycji Śpiewnika kościelnego ks. Jana Siedleckiego, „Teologia i Człowiek” 30 (2015) nr 2, s. 111-128 (DOI: http://dx.doi. org/10.12775/TiCz.2015.024). 
